\title{
Performance Indicators for Training Module Curriculum of Long Term Care
}

\author{
Hsiang-Ping Wang \\ Hungkuang University \\ Liang-Ju Chen \\ Hungkuang University
}

\begin{abstract}
Due to the wide service scopes of elderly in need of care, including medical care, personal caring, social care, and others, the inputs of different professional knowledge are necessary in order to provide the integration of case evaluation and resource management. The training of these professional care givers should be extended to formal educational, including in professional course model and further assist those interested in active integration of theories and practices. This paper uses courses analysis and resource management as core competence to structure the work contents of long term care services, then using this information to design cross professional course contents.
\end{abstract}

\section{INTRODUCTION}

In respond to the aging of population, healthcare education has implemented relating courses, such as geriatric medicine, gerontological care, and rehabilitation for advantaged age. In addition, there are more and more programs on long-term care, gerontological services, senior citizen welfare, and geriatric care to develop necessary professionals in the field (Wang, 2012). In the area of geriatric care, due to their degeneration and weakening, elderly are different from those of other ages in that they are generally limited in self-expressing. Therefore, within technical and vocational education, different levels of educational programs have established core or selective courses in multiple geriatric care or services (Draganidis \& Mentzas, 2006). These include: gerontology, senior living risk assessment, healthcare promotion for elderly, aging population and health care, physiology for elderly, introduction to geriatric medicine, geriatric care services, geriatric nursing, introduction to geriatric healthcare, and long-term care.

Long-term care is a variety of services and supports meet health or personal care needs over an extended period of time for people with disabilities in daily function. The Executive Yuan and subordinate organizations (Minister of the Interior, 2008) have planned and executed many long term care related projects over the near 10 years in response to the increasing aging population of Taiwan. Longterm care is a labor intensive industry. To provide sufficient and high quality care for the individuals needing long term care, it is necessary that educational programs be planned and implemented for professional personnel.

The professional backgrounds required by the current long-term care and the future long-term care insurance system include social workers, nurses, physical therapists, occupational therapists, medical doctors, nutritionists, pharmacists, public health workers and other medical or social specialists. These different professionals were trained to develop specific professional knowledge and skills during their 
school education. However, the goal of long-term care is to solve problems of those in need of care, which include: evaluating needs, formulating care plans, coordinating resources, and care management. Therefore, specific professional training is no longer sufficient for providing efficient long-term care. Hence, it is critical for professional school education to include cross professional care training programs Kolter, 2000).

\section{LITERATURE REVIEW}

\section{Manpower Training}

Population aging will impact a larger percentage of the population creating a greater demand for nursing care facilities and living arrangement (Wang, 2013). Ageing in placing, elders are expected to adjust their daily patterns in home. Long-term care covers home services, day care, home care, and athome rehabilitation (physical and occupational therapy), as well as services that enable disabled people to move freely at home, aging in place, such purchasing and leasing of supplementary equipment and home improvement for easy-access environment and respite support for care givers (Minister of the Interior, 2008).

The need of long-term care from the aging of population in Taiwan has brought recent active promotion of community care in the execution of the aging in place policy. Needs assessment, care plan development and resource management are not only important keys to long-term care, but also the core of care management. In order to improve the quality and equality of services of the manpower in Taiwan, the experiences developed from implementing six years of "Long-term Care Ten Years Project", the current on-job training courses are focusing on fulfilling job competency. However, these courses cannot set up different levels of on-job trainings with different learning objectives and course contents for those with different professional backgrounds. Hence, the job exchanges of these professionals have been frequent.

China should improve professionals and technicians, import capital-intensive and high-tech equipment because of population aging (Hou, 2011). It is imperative for the Chinese government to improve the current health care system to meet the challenges of the long-term health care of the aging population. Managers must be also create personal development plans for associates, pushing courses to individual users as they progress throughout their professional.

The recent experience of the long term care system in Asia, however, considers that a stronger safety net may load financial pressure on the government. Policy maker alike to evaluate the extent to which the private market and the government can substitute family networks in providing the requisite support for the older population in coming years.

\section{Modular Curriculum of Long-term Care}

Due to the wide service scopes of those in need of care, including medical care, personal caring, social care, and others, the inputs of different professional knowledge are necessary in order to provide the integration of case evaluation and resource management. Therefore, different care givers could provide cares needed by different cases. The training of these professional care givers should not only be on-job. If this education could be extended to formal education, including in professional course and further assist those interested students in active integration of practices (Finch \& Crunkilton, 1999).

Implementing cross professional programs that integrating professionals relating to long-term care could provide fast human resource development, however, it is important to systematically discussing course development in competency indicators and course contents, in order to provide immediate practices of professional knowledge and skills. The important issue here is how each professional programs integrating long-term care into its own course structure, teaching objectives and professional competencies that related to course designs and resource allocations. The focus should be on how professional programs develop course modules, and how the course contents keep the specific professional knowledge and skills, while integrate other long-term care relating professional knowledge 
and skills (Vescio, Ross, \& Adams, 2008). With this focus, professional programs would develop students' comprehensive competency in long-term care, such as community resource management, service quality, and case management.

Therefore, this paper uses course analysis and resource management as core competence to structure the work contents of care and services management, then using this information to design cross professional course contents. It aims at discussing cross professional modular curriculums in programs relating to long-term care, follow by skill indicators, and course contents, to provide suggestions for course and performance development.

\section{ANALYSIS OF RESEARCH ISSUES}

\section{Modular Curriculum in Practical Course Development}

Modular curriculum has been implemented in Taiwan's training organizations around 1990's. Since then, it has been widely implemented in educational systems for course design. The major reason for this wide implementation of modular curriculum has been the effectiveness in assisting learning achieving educational objectives (Finch \& Crunkilton, 1999). The idea of modular curriculum is to integrate related courses in accordance with educational objectives, hence providing flexible education, while supplementing courses that could not be provided under limited course requirements. In 2007, the Executive Yuan of Taiwan implemented "Taiwan's ten-year plan long-term care" (Minister of the Interior, 2008), where the Department of Health set up guidelines for professional training in long-term care service management, especially for cross-professional training. Because of the lack of official education in this area, that the current process is to hire relating professionals and to provide concentrated on-job training, in order to improve the competencies in care coordination, management and problem solving.

There are two general used terms: "modular curriculum" and "course module". The course module mainly involves two important concepts: certification guidance; and cross-field, hence, focusing on how certifications guide the planning of cross-field course modules.

Course modularization is the idea course set moving from set menus to buffet, where clients have the maximum selection and deployment of dishes (Warwick, 1988). But, what is a module? Module is a short but comprehensive unit, which could be connected with other units to complete a larger job or longer objectives (Warwick, 1988). Therefore, course modularization is similar to course buffet, where courses could be selected depending on individual interests. In addition to the above unit course modularization, (Finch \& Crunkilton,1999) proposed program course modularization, where related courses are designed into program for specific professional competencies (Table 1). The purpose of this modularization is to individualize education that fit specific learner's educational objectives.

The method of this cross-professional course module design includes review of performance evaluation and course contents offered in the long-term care personnel within Taiwan. Focus group discussion of experts, experienced teachers, and policy maker in the field of geriatric and long term care, and lastly, three working group discussions to review and summarize the key findings. Base on design of education cross professional course module, they overview the concepts, care skills, and community issues of case management in a variety of settings serving older persons.

A. Considering problems at the analysis stage:

1. What are the students' needs?

2. What are the trends of healthcare development and needs of the field?

3. What are educational visions and objectives of the school?

4. What are the core competencies of the professional?

B. Focusing points at the designing stage:

1. Map up required and elective courses that match up with core competencies. (When those maps up courses have been cross fields, then it would be cross field modular courses.)

2. Examine the selected core and elective courses for the logistic of course taking. (I.e.: When the selected courses have been cross fields, different academic departments could have different timing 
for the courses, that it could be overloaded or under loaded for a single semester.)

3. Implementing the course modules after approvals from college and professional experts that in accordance with the regulations.

4. Inviting field experts to examine the properness of the certification guidance course modules.

TABLE 1

ANALYSIS OF CORE COMPETENCE

\begin{tabular}{ll}
\hline \multicolumn{1}{c}{ Occupation } & \multicolumn{1}{c}{ Core Competence } \\
\hline Long-term care & 1. Role and responsibilities of long-term care services \\
& 2.Identification of needs of long-term care cases \\
& 3. Explanation of common practices for long-term care \\
\hline 1. Home care, Home service, & 1. Explanation of service items in long-term care \\
Day care & 2. Identification of home care needs of long-term care cases \\
& 3. Can connect home care resources to satisfy the needs of long- \\
term care cases
\end{tabular}

According above, the core competence for professional programs in geriatric and long term care should include understand long-terms care relating regulations, understand concepts of care management, understand long-term care related issues, understand practical skills in social work, understand service models, familiarized with analysis tools, strive for care service funding, complete working contents of care management, and evaluate and monitor service quality. The recommended courses in geriatric and long term care for each of core competence whenever social work, nursing, physical therapy and occupational therapy programs have been listed in table 2 .

Following performance evaluation, it could recommended that the contents of course. This will ensure that manpower in the nursing, social work services, physical therapy and occupational therapy professionals are exposed to this content knowledge. Nursing, social work, physical therapy and occupational therapy schools are also encouraged to expand the knowledge contents and develop specialized courses, such as geriatric nursing, geriatric physical therapy, case management, care management, geriatric social work, geriatric sociology, geriatric social welfare, geriatric occupational therapy, health education and training. In Table 2, the performance and contents in the course module were explored in concerning of the professional and faulty members' opinions through the approach of interviewing. Secondly, some recommendations about how should we adjust the goals and curriculum planning were developed according to the results of interviewing. Finally, five educational goals and the curriculum planning that can accomplish these seven core competence were proposed by us in this paper. They can be used as the foundation of educational goals and curriculum planning for the future development in performance evaluation for course, and other related course in the field of long term care and education can also reframe their educational goals and curriculum planning according to our research. 
TABLE 2

LONG TERM CARE CORE FIELD COURSE MODULE

\begin{tabular}{|c|c|c|}
\hline Core Competence & Course Titles & Performance Evaluation for Course \\
\hline \multirow[t]{3}{*}{$\begin{array}{l}\text { A. Understand } \\
\text { long-terms care } \\
\text { relating regulations }\end{array}$} & $\begin{array}{l}\text { Senior Citizens } \\
\text { Welfare Act and } \\
\text { Relating Regulations } \\
\end{array}$ & $\begin{array}{l}\text { Understanding important regulations in long- } \\
\text { term care within social and governmental } \\
\text { systems. }\end{array}$ \\
\hline & Public Assistance Act & $\begin{array}{l}\text { 1. Understand the targets of public } \\
\text { assistance } \\
\text { 2. Service contents and items }\end{array}$ \\
\hline & $\begin{array}{l}\text { Introduction to } \\
\text { Health Care } \\
\text { Regulations }\end{array}$ & Service contents and items \\
\hline $\begin{array}{l}\text { B. Understand } \\
\text { concepts of care } \\
\text { management }\end{array}$ & $\begin{array}{l}\text { Introduction to Care } \\
\text { Management }\end{array}$ & $\begin{array}{l}\text { 1. Understand the development and the } \\
\text { trends of long-term care systems in } \\
\text { developed countries } \\
\text { 2. Understand long-term care management } \\
\text { models } \\
\text { 3. Understand the current state, planning, } \\
\text { and execution of long-term care in } \\
\text { Taiwan }\end{array}$ \\
\hline \multirow[t]{5}{*}{$\begin{array}{l}\text { C. Understand } \\
\text { long-term care } \\
\text { related issues }\end{array}$} & Issues in Healthcare & $\begin{array}{l}\text { 1. Identify common diseases in long-term } \\
\text { care cases } \\
\text { 2. Understand health problems of long- } \\
\text { terms care cases } \\
\text { 3. Understand and evaluation dysfunctions } \\
\text { of long-term care cases }\end{array}$ \\
\hline & Issues in Nursing & $\begin{array}{l}\text { 1. Can speak up roles and responsibilities of } \\
\text { long-term care nursing personnel } \\
\text { 2. Can identify nursing needs of long-term } \\
\text { care cases } \\
\text { 3. Can speak up common nursing practices } \\
\text { of long-term care }\end{array}$ \\
\hline & Issues in Social Work & $\begin{array}{l}\text { 1. Can actively discover problems, and } \\
\text { practical methods of problem solving for } \\
\text { long-term care case } \\
\text { 2. Have the social work professional skills } \\
\text { in analyzing and solving problems }\end{array}$ \\
\hline & Issues in drug use & $\begin{array}{l}\text { 1. Understand roles and responsibilities of } \\
\text { pharmacists in long-term care } \\
\text { 2. Can clearly identify common medication } \\
\text { usage problems } \\
\text { 3. Understand common medication } \\
\text { considerations for elderly }\end{array}$ \\
\hline & $\begin{array}{l}\text { Issues in home } \\
\text { environment }\end{array}$ & $\begin{array}{l}\text { 1. Can understand contents and services of } \\
\text { barrier-free facilities, rental and }\end{array}$ \\
\hline
\end{tabular}




\begin{tabular}{|c|c|c|}
\hline & & $\begin{array}{l}\text { purchases of assisting instruments } \\
\text { 2. Can analyze needs of long-term care } \\
\text { cases in functional assisting instruments } \\
\text { and environment reconstruction } \\
\text { 3. Can connect social resources with the } \\
\text { needs of the long-term care cases }\end{array}$ \\
\hline $\begin{array}{l}\text { D. Understand } \\
\text { practical skills in } \\
\text { social work }\end{array}$ & $\begin{array}{l}\text { Practical skills in } \\
\text { social work }\end{array}$ & $\begin{array}{l}\text { 1. Can sympathize with long-term care } \\
\text { cases and possess service passion } \\
\text { 2. Can clearly recognize social work case } \\
\text { skills and methods in long-term care } \\
\text { 3. Can dependently evaluate and provide } \\
\text { effective services to those in needs }\end{array}$ \\
\hline \multirow[t]{5}{*}{$\begin{array}{l}\text { E. Understand } \\
\text { service models, } \\
\text { familiarized with } \\
\text { analysis tools, } \\
\text { strive for care } \\
\text { service funding }\end{array}$} & Care Service & $\begin{array}{l}\text { 1. Care service contents } \\
\text { 2. Can speak up care service regulations } \\
\text { and funding of the long-term care ten } \\
\text { years plan } \\
\text { 3. Can explain relating care service } \\
\text { execution of the long-term care ten years } \\
\text { plan }\end{array}$ \\
\hline & $\begin{array}{l}\text { Purchase and rental } \\
\text { of the assisting } \\
\text { instruments and the } \\
\text { household barrier- } \\
\text { free environments. }\end{array}$ & $\begin{array}{l}\text { 1. Can understand the importance and the } \\
\text { functions of assisting instruments and } \\
\text { home barrier-free environment facilities } \\
\text { 2. Can assess the needs of cases' home } \\
\text { environment } \\
\text { 3. Can assist in the writing and execution of } \\
\text { construction of renting/purchasing plan }\end{array}$ \\
\hline & $\begin{array}{l}\text { Nutritional Meal } \\
\text { Services for Senior } \\
\text { Citizens }\end{array}$ & $\begin{array}{l}\text { 1. Understand geriatric nutritional and } \\
\text { health problems } \\
\text { 2. Understand geriatric diseases and } \\
\text { methods of diet } \\
\text { 3. Understand geriatric nutritional and diet } \\
\text { services and funding of long-term care } \\
\text { ten years plan }\end{array}$ \\
\hline & $\begin{array}{l}\text { Transportation } \\
\text { pickups }\end{array}$ & $\begin{array}{l}\text { 1. Can understand the evaluation methods } \\
\text { and standards for transportation pickups } \\
\text { for care cases } \\
\text { 2. Can assist care cases to plan the best } \\
\text { transportation pickup methods }\end{array}$ \\
\hline & $\begin{array}{l}\text { Institution-base } \\
\text { services of long-term } \\
\text { care }\end{array}$ & $\begin{array}{l}\text { 1. Can understand care service differences } \\
\text { among long-term care institutes } \\
\text { 2. Can search for assistance from long-term } \\
\text { care institute resources and the requiring } \\
\text { regulations } \\
\text { 3. Can apply the above resources to long- } \\
\text { term care institutes }\end{array}$ \\
\hline
\end{tabular}




\begin{tabular}{|c|c|c|}
\hline & Home nursing care & $\begin{array}{l}\text { 1. Can speak up serving elements of long- } \\
\text { term home nursing care } \\
\text { 2. Can identify needs of home nursing in } \\
\text { long-term care cases } \\
\text { 3. Can connect the needs of long-term care } \\
\text { cases with home nursing care resources }\end{array}$ \\
\hline & $\begin{array}{l}\text { Community and } \\
\text { home rehabilitation }\end{array}$ & $\begin{array}{l}\text { 1. Can understand the model of rehabilitation } \\
\text { therapy in long-term care } \\
\text { 2. Can understand serving elements of } \\
\text { rehabilitation therapy in community and } \\
\text { home care } \\
\text { 3. Can identify the needs of long-term care } \\
\text { cases in community and home } \\
\text { rehabilitation } \\
\text { 4. Can connect the needs of long-term care } \\
\text { cases with rehabilitation resources }\end{array}$ \\
\hline & Emergency service & $\begin{array}{l}\text { 1. Can understand the application models of } \\
\text { emergency service } \\
\text { 2. Can identify the needs of long-term care } \\
\text { cases in emergency service } \\
\text { 3. Can connect the needs long-term care } \\
\text { cases with relating resources }\end{array}$ \\
\hline & Respite care & $\begin{array}{l}\text { 1. Can speak up the role and contents of } \\
\text { care givers of dysfunction subject } \\
\text { 2. Can identify caring problems faced by } \\
\text { care givers } \\
\text { 3. Can speak up the needs of major care } \\
\text { givers and the assistances for these care } \\
\text { givers }\end{array}$ \\
\hline \multirow[t]{2}{*}{$\begin{array}{l}\text { F. Complete } \\
\text { working contents of } \\
\text { care management }\end{array}$} & $\begin{array}{l}\text { Multiple service and } \\
\text { resource connection }\end{array}$ & $\begin{array}{l}\text { 1. Can understand the connection and } \\
\text { cooperation among different service } \\
\text { models } \\
\text { 2. Can execute multiple connections of } \\
\text { resources, depending on the needs of the } \\
\text { cases }\end{array}$ \\
\hline & $\begin{array}{l}\text { Case selection and } \\
\text { evaluation }\end{array}$ & $\begin{array}{l}\text { 1. Can explain the procedures od case } \\
\text { management } \\
\text { 2. Can speak up the objectives of case } \\
\text { evaluation } \\
\text { 3. Can explain how to correctly evaluate } \\
\text { cases } \\
\text { 4. Can speak up the importance of case } \\
\text { evaluation } \\
\text { 5. Can correctly complete case analysis and } \\
\text { evaluation } \\
\text { 6. Can identify problems according to }\end{array}$ \\
\hline
\end{tabular}




\begin{tabular}{|c|c|c|}
\hline & & $\begin{array}{l}\text { evaluation results } \\
\text { 7. Can correctly prioritize problems }\end{array}$ \\
\hline & Care plan design & $\begin{array}{l}\text { 1. Can explain the principals of approvals } \\
\text { of care plan } \\
\text { 2. Can explain major skills in care plan } \\
\text { design } \\
\text { 3. Can explain considerations of care plan } \\
\text { designing } \\
\text { 4. Can correctly complete care plan design } \\
\text { 5. Can actively advocate the rights of cases }\end{array}$ \\
\hline & $\begin{array}{l}\text { Referring and } \\
\text { Coordinating } \\
\text { services }\end{array}$ & $\begin{array}{l}\text { 1. Can explain principals of referring and } \\
\text { coordinating services for cases } \\
\text { 2. Can explain mechanism and principals of } \\
\text { referral } \\
\text { 3. Can explain considerations of referral } \\
\text { 4. Can correctly complete case settlement } \\
\text { serving system }\end{array}$ \\
\hline & $\begin{array}{l}\text { Case follow-up, } \\
\text { close-up and } \\
\text { evaluation }\end{array}$ & $\begin{array}{l}\text { 1. Can speak up follow- } \\
\text { up/monitoring/reevaluation mechanism } \\
\text { 2. Can speak up conditions and preparations } \\
\text { of case close-up } \\
\text { 3. Can explain evaluation index }\end{array}$ \\
\hline \multirow[t]{3}{*}{$\begin{array}{l}\text { G. Evaluate and } \\
\text { monitor service } \\
\text { quality }\end{array}$} & $\begin{array}{l}\text { Quality evaluation } \\
\text { and monitoring in } \\
\text { Social and Public } \\
\text { Institutional Service }\end{array}$ & \multirow{3}{*}{$\begin{array}{l}\text { 1. Understand objectives of service quality } \\
\text { management } \\
\text { 2. Understand quality monitoring index } \\
\text { (long-term care service evaluation } \\
\text { contents and index) } \\
\text { 3. Organizations and applications of } \\
\text { quality monitoring } \\
\text { 4. Understand common quality } \\
\text { management problems }\end{array}$} \\
\hline & $\begin{array}{l}\text { Quality evaluation } \\
\text { and monitoring in } \\
\text { Healthcare } \\
\text { Institutional Service }\end{array}$ & \\
\hline & $\begin{array}{l}\text { Quality evaluation } \\
\text { and monitoring in } \\
\text { Community and } \\
\text { home Service }\end{array}$ & \\
\hline
\end{tabular}

\section{CONCLUSION}

Not only elderly, response to Hou (2011) a person who loses their functional will require more services to perform activities of daily living than others will require. These activities would include bathing, using the toilet, eating, and ambulation. Apart from activities of daily living they may also need assistance with instrumental activities of daily living. Needs assessment, care plan development and resource management are not only important keys to long-term care, but also the core of care management.

Changes in demographic structure have led to a rapid increase in the need for long-term care professionals in the senior-care industry. Professional training and human resource needs are topics of concern for government policy makers while planning long-term care systems. A study of human resource training and development trends in the six emerging industries in Taiwan reports that jobs in the field of 
care management have increased in the long term care and elderly services. The need of long-term care from the aging of population in Taiwan has brought recent active promotion of community care in the execution of the aging in place policy. Needs assessment, care plan development and resource management are not only important keys to long-term care, but also the core of care management.

According performance evaluation, healthcare education has implemented relating courses, such as geriatric medicine, geriatric care, and rehabilitation for advantaged age. In addition, there are more and more programs on long-term care, geriatric services, senior citizen welfare, and geriatric care to develop necessary professionals in the field. In the area of geriatric care, due to their degeneration and weakening, elderly are different from those of other ages in that they are generally limited in self-expressing. Therefore, within technical and vocational education, different levels of educational programs have established core or selective courses in multiple geriatric care or services. These include: gerontology, care management, healthcare promotion for elderly, aging population and health care, physiology for elderly, introduction to geriatric medicine, geriatric care services, geriatric nursing, introduction to geriatric healthcare, and long-term care.

Despite of having elderly as the common subject, the designs and developments of these courses should collaborative core foundations. Through the analysis of this paper, the formation of modular courses could be categorized as "program course module". Based on seven core competencies of care management were identified. Table 2 will provide the suggestions for application and evaluation of manpower training cross professional course modules.

Following the course module will examine the various ways the elderly are supported and meted the need of practical training. As well, the module will familiarize students and professionals with possible careers in the field of applied geriatric policy. It also would develop second specialty, and to meet the need of practical training.

In recent years, long term care has become more common and important, and family stress importance on services quality. Accordingly, the author conducted a reflective study of long term care and education module curriculum at the Health Care and Education Department where he had been teaching, so as to better cultivate excellent professionals of long term care and education. In order to achieve this goal, the author first reflected on its planning reasons and then obtained necessary data via curriculum and practicum meetings, interviews, discussions, investigating contents of other schools' long term care and education module curriculum, and collecting relevant literature. Through comparing and contrasting these data, the author disclosed the problems hidden in the module curriculum and developed improvement programs on the aspects of both "skill indicator" and "curriculum content." Further, through communicative interviews of the professionals in the department and the approval of curriculum review committee, the improvement programs can be implemented. Professionals who are interested in long term care and education can reference these programs and this paper's exploration content and indicators to develop suitable module curriculum for geriatric services and health organizations, in order to increase quality care and competitiveness.

Especially, China has undergone tremendous economic and social change since it launched economic reform. It gradually abandoned its closed centralized economic planning system and bringing China into a world market-oriented economy (Tian, 2013a). Long term care and geriatric services are the most important. According to the results of this paper, it is suggested quality monitoring indicators be developed, the job proficiency of the geriatric workers be evaluated regularly, on-job training for the long term care workers be held periodically, the proportion of case number to salary be reasonable and bilingual health care record sheets be developed.

\section{REFERENCES}

Callahan, J. F., Clark, L. H., \& Kellough, R. D. (1992). Teaching in the Middle and Secondary Schools (4th ed.). New York: Macmillan.

Draganidis, F., \& Mentzas, G. (2006). Compentency based management: A review of systems and approaches. Information Management \& Computer Security, 14(1), 51-64. 
Finch, C. R., \& Crunkilton, J. R. (1999). Curriculum development in vocational and technical education, fifth edition. Needham Heights, MA: Allyn \& Bacon.

Hou,Liping. (2011). Challenges and Opportunities: The Impacts of Population Aging on Marketing in China and the Chinese Economy. International Journal of China Marketing, 1(2): 70-80.

Kolter, P. (2000). Marketing management. Englewood Cliffs, NJ: Prentice Hall.

Minister of the Interior (2008). Survey of Disabled People in Taiwan, Taipei: Minister of The Interior.

Moon, B. (1988). Modular curriculum. London: Paul Chapman Publishing Ltd.

Wang, H.P.(2013) Effects of Increase Elderly Females on Ageing Society in Taiwan: Implications in Elderly Service Marketing, International Journal of China Marketing, 3 (2) , 62-71。

Tian, R.G. (2013a). Editorial Commentary: The Rise of Business Anthropology in China. International Journal of Business Anthropology, vol. 4(1), pp. 11-14.

Vescio, V., Ross, D., \& Adams, A. (2008). A review of research on the impact of professional learning communities on teaching practice and student learning. Teaching and Teacher Education, 24(1), 80-91.

Wang HP, Lee ML, Lin CC. (2012). The Changes of Money Income for the Elderly 70 and Older in Taiwan, Journal of Social Behavior and Personality, 40(2):177-188.

Wang, HP (2013) . Effects of Increase Elderly Females on Ageing Society in Taiwan: Implications in Elderly Service Marketing, International Journal of China Marketing, 3 (2) , 62-71。

Warwick, D. (1987). The Modular Curriculum. Oxford: Basil Blackwell.

Acknowledgement: Author gratefully acknowledges support for this project from Taiwan's National Science Council (NSC102-2410-H-241-006). 